\title{
Indians protest against US-led gene bank
}

New Delhi. The ransacking last month of the office of the Indian subsidiary of a US seed company has revived the controversy over a US-Indian project to build a modern seed gene bank and highlighted the often tense relationship between multinational companies and their hosts.

On 29 December, 100 members of a local farmers' association in the southern state of Karnataka broke into the Bangalore office of Cargill Seeds India, a subsidiary of Cargill Inc. of Minneapolis, Minnesota, destroying files and assaulting two Cargill employees. The mob left a note demanding a ban on the entry of multinational companies into the seed business. The raid was led by a retired local agricultural scientist, M.D. Nanjundaiya, and supported by a voluntary organization called the Gene Campaign headed by Suman Sahai, a professor of genetics at the University of Heidelberg.

The protesters fear that Indian farmers will become dependent on the companies for seeds developed from native plants and that, according to Nanjundaiya, "our scientists will be paying hefty royalties to get their own genes back". India opened its doors five years ago to foreign seed companies, and the Gene Campaign has asked 11 of them, including Cargill, to leave the country. "We have resolved to fight for the farmers' right to their genetic resources so that they can manage their own production systems as they have done for hundreds of years", says Sahai.

US and Cargill officials are puzzled by such rhetoric. "We have not patented any Indian gene pool material", says Greg Lauser, a spokesman in Minneapolis for Cargill. The subsidiary in India was formed in 1988 to develop and sell seeds that have been adapted to local conditions, he says, and none of the seed produced in India is exported. Cargill has developed new hybrids of sunflowers, corn and sorghum.

Historically, India has shown little respect for the intellectual property rights of foreign inventors. Only recently, for example, has the government allowed outside seed companies to retain proprietary control over their own material. "I find it particularly ironic that this criticism is coming from a country that does not recognize the rights of others", says Joel Cohen of the US Agency for International Development (AID).

AID is paying 60 per cent of the cost of the \$24-million gene bank now under construction on the campus of the Indian Agricultural Research Institute in New Delhi. When completed in 1994, the gene bank will be able to hold as many as 800,000 accessions and the country will for the first time have the capacity for in vitro, longterm storage of rare and valuable seed lines. Its present system, operated by the National Bureau for Plant Genetic Resources, is al- ready considered the third-best in the world, behind the US facility in Fort Collins, Colorado, and the Vavilov Institute in $\mathrm{St}$ Petersburg.

Despite the obvious improvement in the country's ability to preserve its genetic heritage, some Indian scientists regard the rules under which the new facility will operate as a throwback to the colonial era. "This is a totally one-sided deal", says Vandana Shiva, director of the Research Foundation for Science, Technology and Natural Resource Policy in New Delhi. "While western companies are patenting the contents of their seed banks, India was agreeing to provide open access to its own bank. All that India gets in return are a few seeds of jojoba [an oil-bearing desert plant] and sunflowers."

The Indian government says that the agreement preserves the rights of farmers and does not relinquish control of the country's genetic resources. India already participates in a global system that sends and receives germplasm, says Rai Singh Rana, director of the national plant genetics bureau, and the US contribution will strengthen India's research programme by providing additional equipment, training and opportunities for coliaboration. The genetic characteristics of every seed in the gene bank will be recorded, he adds, ensuring that the origins of any new variety patented can be readily determined.

K.S. Jayaraman

\section{Licences sought from PCR users in Britain}

London. Genetic-screening services throughout Britain could have their costs increase significantly as a result of claims for royalties on one of the basic laboratory techniques used in diagnostic testing, polymerase chain reaction (PCR). This follows the granting over the past few weeks of two patents on the PCR process by the European Patent Office.

The UK Department of Health and the Swiss manufacturer, Hoffmann-La Roche, which holds the patent rights to PCR, are discussing the terms under which hospital laboratories will be permitted to use the technique for diagnostic purposes. The company has told the department that it would like institutions to have licences permitting them to use PCR, a procedure it has adopted with private companies. However, the company is also prepared to negotiate an umbrella licence with the department covering all nonprofit institutions.

Responding to concerns that the licensing fees being demanded by La Roche which would add about 12 per cent to the cost of each screening test - will be a burden to screening programmes being carried out by the National Health Service, the company says that these fees are intended to reflect standard practice in other countries.

"We perceive the British Health Service as a commercial activity, since it is paid for by taxpayers. You cannot say that it is free of charge", says Claude Montandon, director of licensing for Hoffman-La Roche in Basel. If an umbrella licence is agreed to with the health service, he adds, it would be based on an assessment of the "fair market value" of the tests.

The PCR technique, which is used to amplify a short length of DNA allowing it to be characterized, was developed in the early 1980s by Kary Mullis, working at the Cetus Corporation in California. It has become widely used in laboratories around the world.

The rights to PCR were bought by $\mathrm{La}$ Roche in 1991 from Cetus for $\$ 300$ million. Last year, following widespread concern in the research community about the cost of US licences, the company significantly reduced the price (see Nature 355, 379; 1992).

The company has recently demonstrated that it intends to pursue vigorously those thought to be infringing on its patent rights. At the top of its list are companies which it claims are producing and selling $\mathrm{TAQ}$ polymerase - the main enzyme used in the PCR reaction, which is covered by a separate patent - either without a licence or under a licensing agreement that should in principle restrict the sale to non-PCR uses.

The company is concerned that many scientists are buying TAQ polymerase from cheaper sources than the Perkin-Elmer Corporation, which has the sole rights to the sale of TAQ-polymerase for PCR. For example, it has recently sued the Promega Corporation, of Madison, Wisconsin, for breaching an agreement between the two companies under which Promega was permitted to sell TAQ polymerase only to those not using it for PCR.

More difficult for the company to police has been the use of machines other than those produced by Perkin-Elmer for carrying out PCR. The new patent rights awarded to La Roche by the European Patent Office mean that the company can now require anyone using such a machine to carry out PCR to buy a licence. It is this right which underlies the company's current demands on PCR users to enter into licensing agreements.

David Dickson 